\title{
PEMEROLEHAN BAHASA KEDUA PADA TEORI MENTALISTIK BERDASARKAN PANDANGAN ISLAM
}

Oleh

\author{
Novena Ade Fredyarini Soedjiwo ${ }^{1}$
}

Abstract

Second language acquisition in English subject at STAI Denpasar Bali is passed by students as a compulsory subject. Tthe number of students from two study programs, namely Syariah Economics and Islamic Religious Education as samples to determine the acquisition of second language through mentalistic theory with behaviorime and naturalistic approaches based on Islamic views. English as a second language for students is a difficult subject for some students because they rarely or never apply it in their daily activity. Students who are able to apply to the English learning in process, because they remember and often apply it in their environment. The potential that students have is different, because every human being has a fitrah of birth according to his talents and potential.

Key Word: Second Language, Mentalistic, Islamic View

\begin{abstract}
Abstrak
Pemerolehan bahasa kedua dalam mata kuliah bahasa Inggris di STAI Denpasar Bali dilalui oleh mahasiswa sebagai mata kuliah wajib. Dengan jumlah mahasiswa dari dua program studi yaitu Ekonomi Syariah dan Pendidikan Agama Islam sebagai sample untuk mengetahui pemerolehan bahasa kedua melalui teori mentalistik dengan pendekatan behaviorime dan naturalistik berdasarkan pandangan Islam. Bahasa Inggris sebagai bahasa kedua bagi mahasiswa, merupakan mata kuliah yang sulit bagi sebagian mahasiswa karena mereka jarang atau tidak pernah menerapkan dalam kehidupan sehari-hari. Mahasiswa yang mampu dalam mengaplikasikan pada proses perkuliahan bahasa Inggris, karena mereka masing mengingat dan sering menerapkan di lingkungan mereka. Potensi yang dimiliki mahasiswa berbeda, karena setiap manusia memiliki fitrah sejak lahir sesuai dengan bakat dan potensi diri.
\end{abstract}

Key Word: Bahasa Kedua, Mentalistik, Pandangan Islam

\subsection{Latar Belakang}

Bahasa merupakan alat komunikasi antara dua pihak atau sekelompok orang dan dapat dipahami dan dimengerti. Bahasa sebagai alat komunikasi dalam menyampaikan maksud dan tujuan sehingga terjadi interaksi timbal balik. Bahasa memiliki ranah yang luas, hal ini berdasarkan dari bentuk bahasa yang diterima oleh audien, karena bahasa bersifat arbiter.

\footnotetext{
${ }^{1}$ Dosen STAI Denpasar Bali, email noveade@gmail.com
} 
Sebagai warga Negara Indonesia yang memiliki nasional yaitu bahasa Indonesia. Bahasa Indonesia sebagai bahasa ibu bangsa Indonesia tentunya masyarakat secara tidak langsung memahami dan mengerti berinteraksi dengan bahasa Indonesia. Sedangkan bahasa asing yaitu bahasa inggris sebagai bahasa internasional bagi bangsa Indonesia merupakan bahasa kedua, bahkan bias menjadi bahasa ketiga dan seterusnya. Mengingat bangsa Indonesia terdiri dari berbagai suku dan bahasa. Bahasa daerah juga digunakan sebagai bahasa ibu di daerah mereka masing-masing. Sehingga dalam memahami dan mengerti bahasa asing memerlukan proses dan waktu dalam penuturan maupun tulisan.

Bahasa sebagai simbol bunyi yang bermakna dan bersifat konvesional dan arbiter digunakan oleh sekelompok orang dalam berkomunikas yang menghasilkan makna dalam menuangkan perasaan dan pikiran Wibowo (2001: 3). Demikian halnya Ferdinand De Saussure, bahasa sebagai suatu pembeda dimana pada setiap kumpulan masyarakat merupaka satu kesatuan yang bertolak belakang atau memiliki pembeda terhadap sekumpulan kelompok lainnya. Sedangkan menurut Chaer dan Agustina (1995:14) bahasa berfungsi sebagai alat komunikasi. (1993:5) juga sependapat dengan Chaer, bahwa fungsi umum bahasa adalah sebagai alat komunikasi sosial dan tingkah laku sosial, sehingga bahasa dapat dikatakan sebagai alat komunikasi sosial. Dikatakan pula oleh Jeans Aitchison (2008 : 21), "Language is patterned system of arbitrary sound signals, characterized by structure dependence, creativity, displacement, duality, and cultural transmission", bahasa merupakan isyarat yang telah disepakati, yang ditandai dengan terstruktur, berkreasi, sesuai dengan penempatan, dualitas dan transmisi budaya.

Bahasa Inggris sebagai bahasa kedua, setelah menguasai bahasa ibu yaitu Bahasa Indonesia, dimana orang yang menguasai bahasa Indonesia sebagai bahasa ibu (B1), maka apabila orang tersebut mempelajari bahasa Inggris, orang tersebut mempelajari bahasa kedua (B2) dalam memahami memerlukan proses dan pemahaman mempelajari bahasa yang diterima. Dalam mempelajari B2 diperlukan proses kompetensi dan performasi. Seperti yang dikatakan oleh Chaer (2002: 167) bahwa pembelajaran bahasa berkaitan dengan proses-proses seorang anak mempelajari bahasa kedua setelah dia mengenal atau memeroleh bahasa pertama. Proses memperoleh bahasa kedua meliputi pemahaman, penerbitan, dan menghasilkan kalimat-kalimat. Seseorang yang menerima bahasa kedua memiliki ability berbeda antara satu dengan lainnya, tergantung dari bakat, daya serap, dan daya pikir setiap orang berbeda. Seperi yang disampaikan 
oleh Chomsky (dalam Dardjowidjojo. 2005:236) menjelaskan bahwa sesorang memili sistem dan perangkat peraturan (rule-governed). Bahwa seperangkat peraturan tersebut sudah kodrat manusia, yang telah dibekali piranti pemerolehan bahasa.

Sebagai manusia yang memiliki kemampuan yang berbeda untuk memeroleh bahasa tentunya dipengaruhi oleh lingkungan. Seorang anak yang masih murni, belum dipengaruhi oleh lingkungan sekitar. Sehingga dalam perkembangannya terbentuk berdasarkan keinginan lingkungan dalam membentuk kepribadian anak tersebut. lingkungan sekitar diawali dengan orangtua, keluarga terdekat dan guru yang berinteraksi dalam pendidikan anak tersebut. hal tersebut berdasarkan dengan ungkapan John Jocke dan JB Watson mengenai tabularasa (Chaer. 2005). Demikian halnya dengan Skinner (dalam Dardjowidjojo. 2005), bahwa manusia menerima bahasa berdasarkan stimulus dari luar, yang dikendalikan melalui pengamatan dan memanipulasi lingkungan seseorang.

Seorang anak dalam pemerolehan bahasa kedua melalui proses berkomunikasi dan stimulus dengan orang terdekat. Seperti seorang anak berusia 1-3 tahun baru mengenal beberapa kata, dan itupun hanya suku kata, contoh kata "mama". Anak akan mengucapkan "ma...ma" atau "papa", dengan mengucapkan suku kata akhir, yaitu "pa....pa". seorang anak mengamati, mendengar, mengambil, merampas, menyingkirkan dari yang didengar ataupun yan dilihat. Setiap anak memiliki pengalaman dalam mengucapkan kata yang baru ditemui dan diamati selama berinteraksi dengan orang terdekatnya. Demikian halnya dalam proses pembelajaran Bahasa Inggris yang terjadi di perguruan tingg, masih dipengaruhi oleh bahasa ibu mereka. Tampak jelas dalam fonologi, pada saat reading, praktek membaca dipengaruhi oleh logat daerah asal mereka. Sebagai contoh dalam mengucapkan, "I have learning English since some years ago", karena siswa tersebut berasal dari Bima, maka dalam reading logat daerah asal masih terdengar dan makna tidak menunjukkan dari vocabulary yang tersebut di awal, adanya perubahan fonem. Selain itu dalam menterjemahkan dari Bahsa Indonesia ke Bahasa Inggris, mereka msih dipengaruhi bahasa pertama, sebagai contoh: Hasan berdoa bersama di tempat ibadah, diterjemahkan oleh siswa: "Hasam pray together in place worship". Setelah dilakukan koreksi bersama, siswa menyadari adanya kesalahan dalam tata bahasa. Hal tersebut dipengaruhi kebiasaan dalam bahasa pertama tidak memperhatikan atau focus dalam subjek sehingga memengaruhi kata kerja, dan mengalami perubahan apabila subyek adalah orang pertama 
tunggal, sehingga kata kerja ditambahkan huruf "s". siswa menyadari kesalahan yang sering dilakukan.

Berdasarkan fenomena yang sering terjadi di lingkungan sekitar, bahwa penutur mendapatkan bahasa kedua melalui lingkungan sekitar dan stimulus. Pada anak usia 7-12 tahun dalam memeroleh bahasa kedua yaitu bahasa Inggris dalam pendidikan formal merupakan proses pemerolehan bahasa kedua. Tentunya setiap anak memiliki proses yang berbeda satu sama lain.

Banyak pakar yang meneliti pemerolehan bahasa melalui teori-teori sesuai dengan data dari observasi yang telah diperoleh. Dalam penelitian ini, penulis ingin mengetahui proses pemerolehan kedua bahasa melalui pendekatan behaviorism dan teori mentalitik. Metode peneliltian yang digunakan dalam penelitian ini menggunakan metode naturalistik dengan pendekatan kualitatif dan dijabarkan secara deskriftif. Pada penelitian dilakukan dengan natural dengan keadaan yang sebenarnya tanpa menutupi kekurangan yang ada dan dibuat-buat (Sukardi. 2006:3).

Pengambilan data dari mahasiswa Sekolah Tinggi Agama Islam Denpasar Bali semester 1 tahun akademik 2020/2021 program studi Ekonomi Syariah, berjumlah 11 mahasiswa dan program studi Pendidikan Agama Islam, berjumlah 21 mahasiswa. Data tersebut berupa interaksi dalam pembelajaran dan hasil kerja mahasiswa selama semester 1. Dari keseluruhan mahasiswa tersbut, 20\% mahasiswa lulusan Sekolah Menengah Umum tahun 2020/2021. Sisanya sudah lama tidak sekolah, mereka lebih memilih bekerja dahulu. Sekarang mereka bekerja sambil kuliah. Pendapatan yang diperoleh dipergunakan untuk menuntut ilmu strata 1.

\section{Pendekatan Behavior dan Teori Mentalitik}

Behavior secara hirarki merupakan lingkungan sekitar, dengan pendekatan behavior dalam mempelajari bahasa menurut para tokoh behaviorisme yaitu Watson, Skinner, dan Thorndike bahwa pengaruh dalam mempelajari bahasa dan perilaku berdasarkan stimulus dan respon. Hal tersebut sesuai dengan analisa dari Watson (dalam Hamalik. 1990: 154) terhadap seorang anak dalam berperilaku dipengaruhi oleh respon, karena reaksi membalas dari stimulus sekelilingnya termasuk dalam berbahasa. Hal tersebut dibuktikan oleh Watson melalui uji eksperimen yang telah dilakukan pada seorang anak yang awalnya menyukai tikus putih. Dengan memberikan stimulus pada saat anak tersebut akan mendekati tikus putih, melalui hentakan bunyi keras dari besi setiap si anak mendekati tikus putih terus secara berulang. Sehingga si anak 
mulai merasa takut mendekati setiap benda yang berwarna putih, reaksi yang ditimbulkan dari stimulus dan respon yang telah didapat oleh si anak tersebut. dengan pendekatan behavior bahwa seseorang mempelajari bahasa melalui stimulus dan respon sebagai bentuk balasan atas stimulus yang diterima secara berulang sehingga dapat membentuk seeorang tersebut dalam memahami dan mempelajari bahasa secara luas.

Demikian pula oleh Skinner (1957) melalui operant conditioning dan Thordike (18741919) yang dikenal dengan trial and error. Kedua apakar tersebut menunjukan stimulus dan respon saling berkaitan dalam penguatan mempelajari sesuatu sehingga memengaruhi pikiran dan mental dalam mempertahankan dan mempelajari. Seperti halnya dalam mempelajari bahasa, dalam menyampaikan kosakata atau kalimat yang sulit secara berulang dan terus menerus dapat memberikan hasil yang maksimal sesuai yang diharapkan oleh si penerima stimulus (rangsangan) dan memberikan respon (gerak balas). Melalui beberapa eksperimen yang telah dilakukan Thorndike, beliau menemukan hukum latihan (the law of exercise), dan hukum akibat (the law of effect) atau reinforcement (penguatan).

Sedangkan menurut Chomsky, dalam penguasaan bahasa melalui pendekatan behavior dikenal dengan LAD (language Acquisition Device), alat penguasaan bahasa tidak hanya berdasarkan stimulus dan respon terapi dipengaruhi oleh LAD yang dimilki oleh masing-masing manusia dalam penguasaan bahasa yang melupti, membedakan variasi bunyi, penggunaan tata bahasa dalam variasi kalimat, kemampuan beradaptasi dalam penyesuaian bahasa sesuai dengan perkembangannya sehingga diterima oleh lingkungannya. Comsky mekankan bahwa seseorang mampu mengorganisasi bahasa berdasarkan kaidah dan struktur bahasa yang dipelajari/pahami. Dalam pemerolehan bahasa melalui proses pembiasaan, hal ini disebabkan oleh proses pemerolehan bahasa dapat dikatakan sama, tidak ada hubungannya dengan kecerdasan, tidak dipengaruhi oleh motivasi dan emosi, demikian juga dengan tata bahasa yang dihasilkan (Chaer. 2009: 168). Demikian pula yang dikatakan oleh Chomsky, penggunaan bahasa oleh setiap individu dapat kreatif dalam kalimat-kalimat yang dihasilkan bahasa pertama, sejalan dengan pertumbuhan yang dikenal kompetensi intuitif. Kompetensi intuitif ini berjalan sesuai dengan pertumbuhannya, dimana lingkungan memengaruhi proses pemerolehan bahasa pertama. Demikian pula dalam memperoleh akidah dan struktur bahasa dalam bahasa pertama dihasilkan dari proses kompetensi/penguasaan. Kompetensi dalam mengetahui atau memahami 
akidah/struktur bahasa seperti fonologi, morfologi, sintaksis, dan semantik, telah dimiliki individu sejak lahir

LAD merupakan bawaan dari setiap individu dalam pemerolehan bahsa, karena bahsa bersifat abstrak setiap individu memiliki perbedaan dalam memperoleh bahasa yang dipelajari tergantung dari kontak interaksi dengan lingkungan. Teori dalam mempelajari bahasa berdasarkan kajian pada penulisan ini menggunakan teori mentalistik teori ini sama dengan navitisme. Teori ini dipelopori oleh Arthur Schopenhauer (1788-1880), filosof dari Jerman. Dalam mempelajari bahasa dipengaruhi oleh faktor bawaan, sama dengan pendapat dari pakar linguist, Chomsky yang menyatakan bahwa dalam LAD sudah ada sejak lahir, atau bakat yang dimiliki oleh individu tersebut. menurut Arthur, perkembangan bahasa yang diperoleh tergantung dari perkembangan dalam pendewasaan, pembawaan dari individu adalah kompetensi intuitifnya.

Menurut Kusuma dan Nuryani (2013: 67), menyatakan teori mentalistik seorang anak memiliki potensi dan intuisi dalam kematangan berbahasa dimiliki sejak lahir, hingga memiliki kematangan intelektual. Selain itu setiap individu dapat meniru dan mengikuti setiap yang dilihat disekitarnya. Hal tersebut adalah kebiasaan di sekitar individu tersebut sehingga memengaruhi dalam proses menerima bahasa sebagai respon terhadap stimulus yang diterima.

Setiap individu memiliki kemampuan dan potensi diri yang telah dimiliki dari bawaan sejak lahir. Pada saat mereka merespon dalam mempelajari suatu bidang atau bahasa, mereka merasakan kemampuan mereka sendiri dalam memahami dan mengadaptasi dari stimulus yang mereka terima. Seperti yang disampaikan oleh Sunarto dan Hartono (1999: 116-117) bahwa setiap individu memiliki kemampuan dalam menerima respon seperti berbahasa atau bidang lain merupakan keadaan atau sifat dari kemampuan setiap individu. Setiap individu dapat merasakan kemampuannya dalam merespon sesuatu dengan mudah apabila bidang tersebut merupakan bakat alami. Seperti halnya seorang mahasiswa Institute Seni Indonesia Denpasar dengan jurusan musik, akan mudah mempelajari musik karena sudah memiliki bakat yang telah dimiliki sejak lama/sejak lahir. Dengan mendengarkan musik sekali, mahasiswa tersebut dapat mengaplikasikan melalui alat musik seperti piano dengan lancar, walaupun dengan minim kesalahan. Kemampuan tersebut berbeda dengan mahasiswa dari STAI Denpasar, apabila dianjurkan untuk mengaplikasikan musik dengan piano, tidak akan bias sesuai dengan irama 
yang telah didengarkan. Tetapi mahasiswa STAI Denpasar denga mudah dapat mengaji dengan lantunan dan irama sesuai dengan tajwidnya.

Tertulis dalam surat Al-Isro' (17): 18 dengan arti:

“ Katakanlah (Muhammad), "Setiap orang sesuai dengan pembawaannya masing-masing. Maka Tuhanmu lebih mengetahui siapa yang lebih benar jalannya".

Sepeti isi dari ayat tersebut di atas menjelaskan bahwa manusia memiliki kemampuan dan bakat yang berbeda-beda. Telah dikatakan dalam Alquran bahwa manusia memiliki pembawaan masing-masing sejak lahir. Melalui proses perkembangan manusia bakar di asah atau diperoleh melalui lingkungan yang mendukung sehingga memunculkan minat dalam melancarkan bakat yang telah dimiliki. Lingkungan juga memengaruhi keinginan dalam menjalani kemampuan sesuai dengan bakatnya. Bakat dalam setiap individu dipengaruhi oleh minat sehingga berkesinambungan dengan keinginan, perhatian, dan fokus dalam merespon bidang tertentu yang diminati. Hal tersebut saling mendukung, sehingga proses perkembangan dalam merespon berjalan sesuai dengan keinginan dan terkadang hal tersebut tanpa disadari karena mengalir dengan sendirinya. Keadaan ini menunjukkan bahwa bakat seseorang memengaruhi keinginan mereka.

Pemerolehan Bahasa Kedua dalam Pandangan Islam

Pendekatan behavior dalam pemerolehan bahasa pada mahasiswa STAI Denpasar selama mengikuti mata kuliah Bahasa Inggris dapat dilihat pada saat mereka mengikuti perkuliahan dengan pertemuan 90 menit setiap pertemuan, dengan melakukan pembelajaran aktif 14 kali pertemuan. Pembelajaran dilakukan dengan interaksi dan pemberian tugas. Dimana selama pandemi dilakukan melalui daring. Keterbatasan dalam pembelajaran daring tentunya telah diketahui secara global, mengingat bahasa harus bertatap muka dan berdialog dalam pemberian perkuliahan. Dengan keterbatasan tersebut, penulis mencoba menganalisis dengan data dari mahasiswa. Pengamatan secara keseluruhan mahasiswa dengan jumlah mahasiswa 32 dari dua program studi dan dengan latar belakang berbeda, dipegaruhi oleh lamanya mereka tidak mengenal bangku sekolah. Hal ini akan memengaruhi potensi mereka dalam mengaplikasikan mata kuliah Bahasa Inggris.

Dalam proses perkuliahan diantara 32 mahasiswa tersebut $20 \%$ tidak langsung melanjutkan kuliah, mereka bekerja dan kemudian melanjutkan kuliah dengan alasan mencari 
ijazah. Hal ini menunjukkan minat dalam perkuliahan bahasa Inggris tidak ada ketertarikan atau mereka berkewajiban mengikuti perkuliahan tersebut, karena wajib untuk diikuti sesuai dengan KHS yang harus ditempuh. Selama mengikuti perkuliahan, sebagian besar belum menunjukkan potensi/kemampuan dalam bahasa Inggris, baik dalam membaca ataupun menulis dengan tatabahasa sesuai dengan kaidah bahasa Inggris. Untuk memudah dalam menganalis penulis menyajikan dalam bentuk tabel 1, dalam empat aspek mempelajari bahasa di bawah ini.

Tabel 1. Analisis 4 Aspek dalam Bahasa Inggris.

\begin{tabular}{|c|c|c|c|}
\hline Listening & Speaking & Reading & Writing \\
\hline 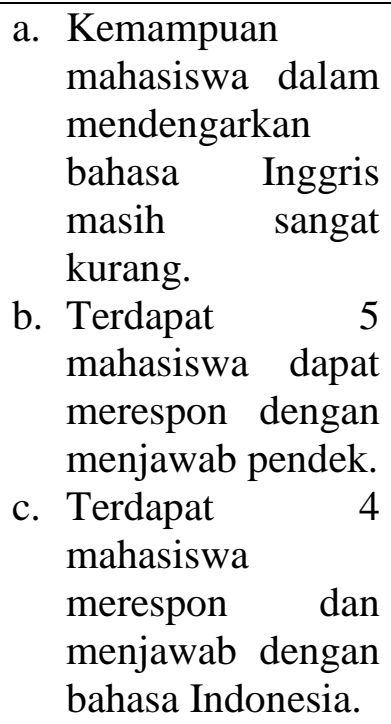 & $\begin{array}{l}\text { d. Kemampuan } \\
\text { mahasiswa dalam } \\
\text { berbicara masih } \\
\text { sangat kurang. } \\
\text { e. Terdapat } \\
\text { mahasiswa } \\
\text { berbicara dengan } \\
\text { menggunakan } \\
\text { bahasa Inggris. }\end{array}$ & 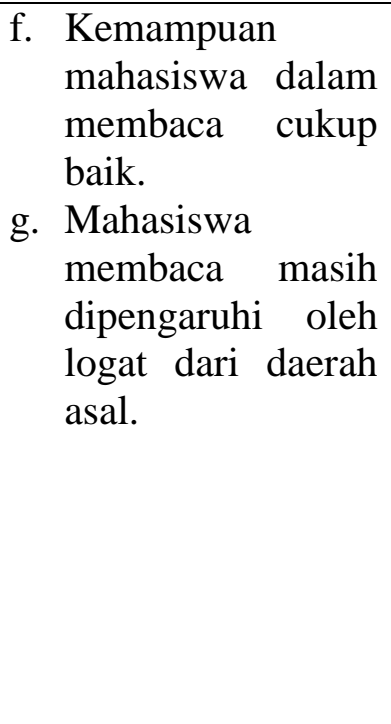 & $\begin{array}{l}\text { h. Kemampuan } \\
\text { mahasiswa cukup } \\
\text { baik. } \\
\text { i. Kesalahan } \\
\text { dijumpai pada } \\
\text { perubahan tense. } \\
\text { j. Penguasaan } \\
\text { kosakata masih } \\
\text { kurang. }\end{array}$ \\
\hline
\end{tabular}

Berdasarkan tabel di atas menujukkan bahwa kemampuan mahasiswa setiap kategori kurang dalam menguasai bahasa Inggris. Merujuk pada poin (a), menyatakan bahwa mahasiswa kurang dalam mendengarkan bahasa Inggris, karena mereka kurang merespon, sebagian besar dari mahasiswa terdiam. Kemudian setelah diberikan stimulus dengan mengulang secara perlahan, lima mahasiswa dapat merespon dengan menjawab singkat. Tetapi pada saat memberikan pertanyaan umum, seperti bertanya identitas diri, lima anak dapat menjawab dengan baik, sesuai dengan poin (b). Dimana mahasiswa menjawab dengan menggunakan basa Indonesia pada poin (c). Empat mahasiswa tersebut menggunakan bahasa Indonesia karena mengerti arti bahasa Inggris, tetapi tidak percaya diri untuk menjawab dengan bahasa Inggris.

Mereka mampu menjawab pertanyaan umum, seperti tema interduce yang selalu diberikan masih melekat dipikiran mereka dan sudah terbiasa mendengarkan introduce dan greeting. Tema tersebut selalu diberikan di awal mereka studi, sehingga terus dilatih dan 
dipraktikan selama di bangku sekolah. Sedangkan dengan tema berbeda dengan mendengarkan dari teks pendek, mereka masih kesulitan pada aspek mendengarkan.

Pada poin (d), sebagian besar mahasiswa tidak dapat berbicara dalam bahasa Inggris secara langsung. Tetapi apabila mereka diperintahkan untuk membuat kalimat, mereka mampu menunjukkan kalimat pendek dalam bahasa Inggris. Tetapi hal ini juga tidak valid, karena sebagian besar masih menggunakan google translate. Hal ini tampak pada saat memberikan tugas melalui daring dengan wattsap, mereka dapat menerjemahkan dengan baik tidak ada kesalahan. Tetapi pada saat interaktif melalui daring yaitu zoom, mahasiswa diperintahkan untuk menerjemahkan kalimat secara langsung, masih banyak yang belum dapat menunjukkan hasil yang benar. Teknis untuk mengetahui bahwa mahasiswa tidak dapat menunjukkan hasil membuat kalimat, mahasiswa diberi soal yang berbeda, dan sebagian besar tidak dapat menunjukkan kalimat dalam bahasa Inggris dengan benar. Alasan mereka karena lupa beberapa kosa kata dan penggunaan "to be" dalam kalimat karena dipengaruhi oleh keterangan waktu (adverb of time).

Pada poin (e), terdapat lima mahasiswa menunjukkan kalimat bahasa Inggris dengan benar. Tema pembelajaran bahasa Inggris yang diberikan, menceritakan kegiatan sehari-hari yang biasa dilakukan (daily activity). Pada tema tersebut, sudah dipelajari oleh mahasiswa pada jenjang sekolah dan merupakan tema wajib yang diberikan pada tingkat dasar dalam pembelajaran bahasa Inggris. Sedangkan siswa lainnya harus dituliskan dalam bahasa Indonesia kemudian di terjemahkan ke Bahasa Inggris. Mereka masih kurang dalam menguasai kosakata bahasa Inggris. Dalam penguasaan kosakata diperlukan latihan secara berulang, apabila jarang diterapkan dalam kehidupan sehari-hari akan mengalami short memory.sedangkan mahasiswa yang mampu dalam mempraktekkan speaking, karena mereka memiliki kelebihan dalam mengingat kosakata dan tatabahasa Inggris yang telah mereka pelajari sebelumnya (long memory). Pada piranti pemerolehan bahasa, Pateda (1990:47) bahwa stimulus dan respon sangat terbatas, dalam mempelajari bahasa dipengaruhi pula oleh makna, abstraksi, dan kreativitas. Tiga aspek tersebut merupakan bagian dari bawaa sejak lahir, sehingga dikatakan sebagai bakat alami yang dimiliki, mampu mengingat dalam waktu lama atas apa yang telah dipelajari dan bagian dari pengalaman dalam mempelajari bahasa Inggris, selain itu lingkungan mereka memengaruhi dalam mempraktikkan bahasa Inggris. Sebagai contoh, mahasiswa yang bekerja 
pada travel dan cargo yang berhubungan dengan orang asing. Secara tidak langsung memengaruhi kemampuan dalam menerapkan speaking.

Pada poin (f) dan (g) sebagaian mahasiswa mampu menunjukkan kemampuan reading dengan benar. Ada beberapa mahasiswa yang kurang benar dalam pronounciation. Kesalahan dalam reading ditemukan pada saat membaca "but", mahasiswa menyebutnya 'but', menurut bahasa Inggris membacanya adalah ' $b \Lambda t$ ' (bat). Kemudian artikel 'the' pada kalimat: “The animal and plant are livingthing created Allah'. 5 mahasiswa membaca 'the' adalah 'do', pronountition pada 'the' adalah ' $d i$ '. pengucapan 'the' berubah karena huruf depan pada kosakata 'animal' adalah vocal, sehingga 'the' harus di baca 'di'. Hal tersebut, mahasiswa tidak atau jarang membaca teks bahasa Inggris selama tidak bersekolah. Selain itu bahasa Inggris hanya dijumpai pada saat mereka studi atau di tempat bekerja, yang berhubungan dengan tamu asing. Jarangnya penggunaan bahasa kedua dalam kehidupan sehari-hari menyebabkan tidak terbiasa membaca dengan kaidah dan aturan dalam bahasa Inggris. Tetapi sebagian mahasiswa mengetahui perubahan artikel apabila di depan kosakata adalah huruf vocal, karena tidak terbiasa mereka tetap membaca ' $d \partial$ ', setelah ditegur atau dijelaskan, mereka menyadari bahwa mereka sudah endapat penjelasan sebelumnya pada jenjang pendidikan sebelumnya. Selain itu pada reading masih dipengaruhi oleh logat daerah asal mereka, sehingga pronounciation tidak sesuai, sehingga tidak diketahui artinya apabila tidak melihat teks bacaan. Mahasiswa tersebut berasal dari NTB dan NTT. Hal ini masih dipengaruhi oleh lingkungan mereka dalam berbahasa, sehingga memerlukan waktu untuk beradaptasi dengan bahasa kedua, karena mereka telah berusaha mendemontrasikan reading dari teks pendek.

Pada poin (h), mahasiswa mampu menunjukkan dan mepresentasikan hasil writing dari materi yang telah diberikan. Tetapi apabila membuat kalimat secara langsung, masih dijumpai kesalahan yang tersebut pada poin (i), mereka masih belum memahami dengan baik perubahan 'to be' dalam sebuah kalimat. Karena kaidah dan aturan dalam bahasa Inggris saling memengaruhi, baik subject, verb, dan adverb of time. Demkian halnya pada poin (j) juga memengaruhi pada saat mereka mencari kosakata dalam membuat kalimat. Sebagian besar lupa dan mencari arti dalam kamus atau google translate. Kesalahan yang dijumpai dalam writing, tampak pada tatabahasa (grammar).

Secara keseluruhan mahasiswa telah berusaha sebaik mungkin dalam mengikuti pembelajaran bahasa Inggris dasar di STAI Denpasar. Hal tersebut dibuktikan dengan keaktifan 
mereka pada saat perkuliahan dan menyetorkan tugas tepat waktu. semangat dan keinginan untuk belajar sudah terlihat. Semangat mereka memotivasi membangkitkan pikiran positif agar bisa berbahasa Inggris. Seperti yang terdapat dalam surat Al Baqorah ayat 216, yang berbunyi:

"dan boleh jadi kamu membenci sesuatu tetapi baik bagimu. Dan boleh jadi kamu menyukai sesuatu tetapi ia buruk bagimu. Dan Allah mengetahui dan kamu tidak mengetahui".

Sebagai umat manusia dengan mendapat akal dan pikiran atas rahmat yang telah di berikan Allah, hendaknya manusia menjalani dengan ikhlas dalam kehidupan sehari-hari sehngga mempermudah dalam melaksanakannya. Dengan mengikuti pembelajaran bahasa Inggris, walau tidak bisa tetap melaksanakan kewajiban sebagai mahasiswa dengan baik. Apabila tidak menyukai dan membenci pelajaran tersebut akan berakibat buruk, seperti yang tersirat dalam ayat Al Baqarah, hal tersebut dapat berakibat dalam keaktifan dalam kelas, jumlah kehadiran, dan penurunan penilaian. Sehingga memengaruhi jumlah KHS dalam perkuliahan dan apabila nilai tidak sesuai standar kelulusan, memerlukan waktu untuk perbaikan nilai dan menambah anggaran penyelesaian perbaikan nilai. Mengingat pelajaran bahasa Inggris dalam perkuliahan merupakan mata kuliah wajib umum yang harus diikuti, agar mahasiswa mengetahui dan menguasai bahasa Inggris dasar, sebagai upaya membantu pada saat mendapatkan buku kajian ilmiah berbahasa Inggris dari salah satu ketentuan literature pada kelengkapan perkulihan.

Pada masa mendatang akan mendapatkan hikmahnya, suatu ilmu yang dipelajari suatu saat akan berguna bagi lingkungan sekitar. Sebagai contoh, salah satu alumni STAI Denpasar Bali program studi PAI, yaitu Pamela. Sekarang dia mengajar di salah satu sekolah dasar. Pamela mengajar tematik dan memperbantukan di pelajaran bahasa Inggris. Tentunya membantu Pamela pada saat memberikan materi pada pelajaran tersebut, dan Pamela aktif menghubungi dosen bahasa Inggris di STAI Denpasar dalam memperdalam tatabaha bahasa Inggris (wawancara Pamela. 28 Oktober 2020). Sesuatu yang telah dipelajari dan merupakan pengalaman dalam hidup, pastinya akan berguna pada suatu saat. Seperti janji Allah, bahwa apabila manusia berusaha berpikir positif dan berusaha menjalani dengan ikhlas, tentunya akan menjadi baik dan Allah mengetahui itu. Manusia mendapatkan fitrah sejak lahir baik jasmani dan rohani. Fitrah tersebut memiliki potensi untuk dikembangkan dalam perkembangannya sehingga keberadaannya memiliki makna selaras dengan prinsip ketauhidan. Fitrah yang telah dimiliki dapat menerima pengaruh dari keturunan dan lingkungan sekitar. Seperti ungkapan Achmadi 
(2005: 43) bahwa potensi akal secara fitrah manusia dapat memahami symbol-simbol, abstrak, menganalisis, membandingkan, memilah kebenaran dan keburukan. Selain itu manusia dengan iptek dapat berkreasi dan berinovasi dalam menciptakan kebudayaan dan peradaban sesuai dengan jamannya dalam mencapai kesejahteraan.

Demikian halnya dalam mempelajari bahasa Inggris diperlukan latihan dan praktik secara berulang untuk memperlancar dan memahami bahasa Inggris dengan baik. Diperlukannya mental yang baik untuk mendemontrasikan bahasa Inggris melalui speaking. Banyak mahasiswa yang malu untuk speaking di dalam kelas pada saat mata kuliah bahasa Inggris. Sehingga mereka enggan untuk menunjukkan kemampuannya. Mereka lebih senang menulis (writing). Dengan bimbingan dan motivasi dalam mengarahkan saat pelajaran bahasa Inggris, mahasiswa dengan terpaksa harus menunjukkan kemampuan diri pada aspek speaking.

Merujuk pada teori mentalistik, bahwa sesorang memiliki bakat sejak lahir dan dipengaruhi oleh lingkungan sekitar. Demikian halnya seseorang dalam mempelajari bahasa Inggris, akan terlihat kemampuan masing-masing mahasiswa pada proses pembelajarannya seperti, pronounciation, respon in direct, and spontaneous in English. Semua aspek bahasa Inggris akan terlihat dan setiap orang memiliki kemampuan berdasarkan skill yang telah mereka lalui baik dalam pengalaman studi dan pengalaman pada lingkungan mereka. Hal ini juga ditunjukkan pada bidang lain yang diminati oleh mahasiswa lainnya, setiap individu memiliki minat bakat sesuai bidangnya, tidak bisa dipaksakan. Bidang yang diminati tentunya akan diiringin dengan pengembangan atas bakat yang telah dimiliki, sehingga dalam proses pembelajaran akan terbentuk dengan sendirinya dan lebih menonjol daripada mahasiswa lainnya.

Language acquisition device yang dimiliki oleh seoranga anak, menurut Chomsky seorang linguish, pada dasarnya setiap manusia telah memiliki intelektual dalam otaknya dan dibekali kemampuan berbahasa bawaan sejak lahir. Pada perkembangnnya manusia akan mengalami proses dalam berbehasa melalui pembelajaran atau pemerolehan bahasa, terus mengingat dan berusaha melatih terhadap yang telah dimiliki dalam diri, baik dalam berkomunikasi dan berinteraksi berbahasa. Semakin dewasa seseorang akan mengalami penurunan kemampuan penguasaan, tidak secepat perkembangan seorang anak. Akan tetapi kemampuan orang dewasa terlihat dalam kemampuan menguasai tatabahasa lebih baik.

Berdasarkan pandangan Islam yang memjelaskan bahwa fitrah dimiliki sejak lahir dan memlalui fitrah tersebut manusia dapat mengembangkan keilmuan dan bahasa yang dikuasai 
melalui proses pendidikan yang dipengaruhi oleh lingkungan. Potensi setiap manusia yang dimiliki akan berkembang menurut cara pandang dan pikir yang dipengaruhi oleh lingkungannya.

\section{Kesimpulan}

Mahaiswa STAI Denpasar Bali dalam mengikuti pembelajaran bahasa Inggris sesuai dengan jadwal dan ketentuan kampus, telah dilaksanakan dengan baik. Kemampuan dari masingmasing mahasiswa berbeda-beda dipengaruhi oleh internal dan eksternal, yaitu kemampuan kognitif dan lingkungan sekitar. Sebagai manusia yang memiliki fitrah sejak lahir dapat mengembangkan potensi atau bakat yang dimiliki dengan potensi diri dan lingkungan sekitar.

Dalam menguasai pemerolehan bahasa kedua telah diketahui bahwa sebagian besar mahasiswa belum menguasai baik speaking, listening, reading, dan writing. Mereka terlalu lama tidak di bangku pendidikan, tidak di lingkungan yang menggunakan bahasa Inggris, dan kurang tertarik dengan bahasa Inggris. Dipengaruhi juga dengan lingkungan yang tidak mendukung untuk mengetahui lebih sering dan berulang berbahasa Inggris.

Pemerolehan bahasa kedua berdasarkan pandangan Islam menurut teori mentalistik, mahasiswa STAI Denpasar belum menunjukkan potensi diri atau bakat yang dimiliki secara keseluruhan, masih di bawah rata-rata tingkat kemapuan pada empat aspek bahasa Inggris. Potensi diri yang dimiliki sejak lahir sebagai fitrah mampu meningkatkan dan mengembangkan potensi diri menjadi lebih baik melalui proses pembelajaran dan lingkungan yang mendukung sehingga tercapai tujuan untuk lebih memahami dan mengetahui bahasa kedua, yaitu bahasa Inggris. Usaha dalam peningkatan potensi melalui motivasi dan keinginan untuk lebih intensif, khususnya bahasa Inggris, yang merupakan salah satu mata kuliah wajib bagi mahasiswa. Seperti yang tersirat dalam Alquran, bahwa sebagai manusia harus berusaha untuk menjadi lebih baik dengan menunjukkan potensi yang dimiliki dengan memanfaatkan kesempurnaan sebagai mahkluk ciptaan Allah.

\section{Daftar Pustaka}

Achmadi. 2005. Ideologi Pendidikan Islam (Paradigma Humanis Teosentris). Yogyakarta: Pustaka Pelajar. 
Aitchison, Jean. 2008. The Articulate Maamal: An Intriduction to Psicolinguistic. Fifth Edition. London and New York: Routlegde.

Chaer, A. dan Leoni Agustina. 1995. Sosiolinguistik: Suatu Pengantar. Jakarta: Rineka Cipta.

Chaer, A. 2002. Pembakuan Bahasa Indonesia. Jakarta: Rineka Cipta. 2009. Pengantar Semantik. Jakarta: Rineka Cipta.

Dardjowodjodjo. 2005. Psycolinguistic. Jakarta: Yayasan Obor Indonesia.

Hamalik, Oemar. 1990. Psikologi Belajar dan Mengajar. Bandung: Sinar Baru Algensindo.

Skinner, B.F. 1957. About Behaviourism. New York: Knopf.

Sunarto dan Hartono. 1999. Perkembangan Peserta Didik. Jakarta: Rineka Cipta.

Wibowo Wahyu. 2001. Manajemen Bahasa. Jakarta: Gramedia Pustaka Utama. 